\title{
The Extent of Compatibility of Accounting Curriculum with the Requirements of Accounting Profession in Labor Market and IT Environment: Field Study in Jordanian Higher Education and Scientific Research Institutes
}

\author{
Reem Okab Kasswna ${ }^{1}$ \\ ${ }^{1}$ Al-Balqa Applied University, Jordan \\ Correspondence: Reem Okab, Al-Balqa Applied University, Jordan. E-mail: medeoheart2000@yahoo.com
}

Received: October 29, 2018

doi:10.5539/ijbm.v14n1p192

Accepted: November 24, 2018

Online Published: December 23, 2018

URL: https://doi.org/10.5539/ijbm.v14n1p192

\begin{abstract}
The Purpose of the study: The study aims is to identify the extent of compatibility of accounting curriculum with the requirements of accounting profession in labor market and IT Environment Jordanian Higher Education and scientific Research Institutes. Such requirements include general and specialized scientific skills and knowledge that accountants need to have in IT environment.

The methodology of the study: The researcher has used descriptive analytical method. Previous studies and international standards of accounting education, touching upon the most important knowledge and skills that the accountants need to have as requirements of Jordanian labor market have been reviewed. In addition, the researcher designed and distributed a questionnaire to a research sample of the accountants working at Jordanian companies.

Findings: The study concluded that the accounting courses taught in Jordanian higher education and scientific research institutes include the most significant knowledge and skills required in Jordanian labor market and ICT (Information and Communication Technology) environment. And they are inserted in some courses but are not detailed. Moreover, the study referred that attention should be paid to the developments of accounting curricula in order to comply with the development of ICT, recently used.
\end{abstract}

Keywords: accounting education, information technology (IT), higher education and scientific research institutes

\section{Introduction}

Higher education, the main pillar of meeting the needs of human development and labor work, plays an important role in creating a trained workforce able to communicate with the world and deal effectively with the updates. The importance of accounting education comes from accounting's importance and its benefits it provides the society with. Accounting is an organized profession that records, classifies and summarizes economic events in a logic manner for the purpose of providing financial information which can be used by the bodies related directly or indirectly to economic unit. In addition, accounting is one of social sciences characterized by a classified knowledge and it has a scientific material that could be accessible through study and experience. Accordingly, practicing accounting work needs employees scientifically qualified and the ability to judge various matters that fall within accounting work field.

It is clear that interesting in accounting and the need to provide the scientific basis of teaching and practicing accounting have emerged and developed due to the emergence of practicing various commercial works and the necessity of measuring the results and providing data the concerned people and entities need.

Due to rapid development of information technology and communication networks plus the emergence of the international information network, traditional form of economic movement has been rapidly transformed into electronic form; various public and private institutes and enterprises have also begun to set up their websites in order to practice (commodity or service) e-commerce and pay the prices electronically. At the beginning of the third millennium, electronic accounting was introduced as one of the contemporary concepts of information technology based on high demand of e-commerce and e-purchasing. 
In ICT environment, accountant has to use digital tools in the fields of accounting record and analysis using the computer and international information network. Accounting software based on international information network (internet) is a renewable source of (local and international) accounting data and information, international databases and data collection methods. Furthermore, using information technology has contributed to the diversification of accountant work's fields and tasks ranging from data entry in electronic systems to information system manager and information system designer and analyst. Such practical reality imposes various IT skills and knowledge on accountants in order to perform appropriately their tasks and roles.

Here, universities play an important role in qualifying the accountants who are able to perform their tasks in IT environment. Therefore, higher education institutes are developing accounting curricula in order to comply with the requirements of accounting work fields in IT environment.

In this study, the researcher seeks to study the extent of compatibility of Jordanian universities' accounting curricula with the requirements of IT environment. The researcher also seeks to identify the important role of the universities in developing the curricula which qualify the accountants in order to perform their accounting tasks in IT environment through providing the fundamental skills and knowledge. Consequently, the accountants become able to perform their jobs if they work as system mangers, electronic system designers or evaluators.

\subsection{The Importance of the Study}

The recent study is important due to the importance and vital role of accounting education; it is not only qualify the accountants for the labor market but also continuously develop the capabilities of accountants in order to cope with economic changes that influence accounting profession. The importance of the study is illustrated by the following:

1. Identifying the significant public knowledge pertaining to information technology, which the accountant has to have in order to perform accounting tasks in information technology environment and to which extent it is available in accounting curricula.

2. Identifying the most significant knowledge and skills which the students have to have in order to work in the capacities of electronic system employees, managers, designers, and evaluators and to which extent they are available in accounting curricula.

3. Identifying to which extent control - related knowledge and skills in IT environment are available in accounting curricula of Jordanian universities.

This study is useful for higher education and scientific research institutes since it contributes to develop study plans and touches upon the most significant IT knowledge and skills which accounting students have to know in order to meet the requirements of labor market according to the standards of accounting education.

\subsection{The Problem of the Study}

The problem of the study is to identify to which extent the accounting curricula cope with the technical changes, the use of electronic systems and communication networks depending on curricula taught in accounting departments of Jordanian universities. The study illustrates the changes required in the curricula according to the developments of information technology and communication fields. It also studies the relationship between the requirements of labor market including skills and knowledge the accountants, working as users, designers and managers of electronic system, need to have in the field of information technology and the curricula of accounting departments in Jordanian universities through answering the following questions:

- To which extent the outputs of accounting education in Jordanian higher education and scientific research institutes are compatible with the requirements of Jordanian labor market?

- Do accounting curricula taught in Jordanian higher education and scientific research institutes include general knowledge related to IT which the accountant has to know well?

- Do accounting curricula taught in Jordanian higher education and scientific research institutes include the knowledge and skills which the students have to know well in order to work in IT environment as electronic system users?

- Do accounting curricula taught in Jordanian higher education and scientific research institutes include knowledge and skills related to the control in IT environment?

- Do accounting curricula taught in Jordanian higher education and scientific research institutes include the knowledge and skills which the students have to know well in order to work in IT environment as electronic system managers, designers and evaluators? 
- Do accounting curricula taught in Jordanian higher education and scientific research institutes illustrate profession ethics?

\subsection{The Purposes of the Study}

The study aims at identifying the extent of compatibility of educational programs applied on accounting departments of Jordanian higher education and scientific research institutes with ICT requirements in labor market. To achieve the purpose of the study, the researcher identifies the important knowledge and skills that the undergraduates, who study accounting have to know. The researcher also illustrates the most significant knowledge and skills which qualify the students to work in the capacity of electric system's users, managers, designers and evaluators in IT environment. In addition, the most important knowledge and skill related to control principle which must be stated in accounting curricula of Jordanian higher education and scientific research institutes are identified.

\subsection{The Hypotheses of the Study}

Along with other disciplines, accounting education occupies an importance place due to accounting specificity and continuous need to accounting work of business organizations and labor market. At present, accounting depends on using electronic methods in order to do transactions and prepare reports. Therefore, accountants have to have special self-abilities of using electronic systems in order to perform accounting tasks and prepare reports. In addition, accounting education plays a significant role in preparing accounting electronic systems. Consequently, possessing practical and scientific information of IT technology becomes a necessity. As a result, this study tests the following set of hypotheses:

1. Accounting curricula taught in Jordanian higher education and scientific research institutes include general knowledge which the accountant has to know well in order to meet the requirements of Jordanian labor market and IT environment.

2. Accounting curricula taught in Jordanian higher education and scientific research institutes include the knowledge and skills which meet the requirements of Jordanian labor market and qualify the students to work in IT environment in the capacity of electronic system users.

3. Accounting curricula taught in Jordanian higher education and scientific research institutes includes control- related knowledge and skills which meet the requirements of Jordanian labor market and IT environment.

4. Accounting curricula taught in Jordanian higher education and scientific research institutes include the knowledge and skills which qualify the accountants in order to work in IT environment in the capacities of electronic system managers, designers and evaluators and meet Jordanian labor market.

\subsection{The Methodology of the Study}

The researcher has used descriptive analytical method depending on previous relevant studies and vocational accounting education standards issued by Federal of Legal Accountants; the most important knowledge and skills that qualify the accountants to work in IT environment have been illustrated.

At field, the researcher designed and distributed a questionnaire to a random sample of the accountants working in Jordanian companies. The questionnaire relates to the most significant skills and knowledge the accountants have to have in order to meet the requirements of working in IT environment. It contains four axes identified as follows:

First Axis: it relates to the general knowledge the accountant has to know in IT environment and includes 13 paragraphs.

Second Axis: it relates to the knowledge and skills which qualify the students to work in the capacity of electronic system users and IT environment and includes 9 paragraphs.

Third axis: it relates to control-related knowledge and skills in IT environment and includes 9 paragraphs.

Fourth axis: it relates to the knowledge and skills which qualify the student to work in the capacities of electronic system managers, designers, and evaluators in IT environment and includes 25 paragraphs.

\section{Previous Studies and Theoretical Framework}

The most important previous studies relevant to the study are reviewed as follows:

Naasah, Khamis, (2009) study aimed at identifying the effect of participating the accountants in the stages of development of accounting information systems used by joint-stock companies and their effect on companies' 
financial performance; two researchers studied 39 companies that used accounting information system. They distributed 147 questionnaires and used companies' financial statements in order to test the effect of using accounting systems in financial performance. In addition, they used eight financial indicators to measure financial performance.

The study found that there is a statistically significant relationship between the participation of accountants in the stages of development of accounting information systems and systems' performance. Compared to other stages of development, participating in implementation stage had the greatest effect on system development. It also identified that except for the ratio of operational income to sales, there were no statistically significant differences between financial performance indicators before and after implementing the system. And the study found that there are statistically significant differences between the financial performance indicators of the companies applied computerized systems and financial indicators of the companies that do not apply such systems.

Bofares (2007) study: presented a strategic framework of educational process in the field of accounting, using the professional accounting education program prepared by federal of international accountants. In the study, the standard educational program has been compared to The recent education program through three axes: (1) professional accounting curricula, (2) teaching methods, and (3) practical experience. The study presented some suggestions extracted from the recommendations of education committee of the international federal of accountants in order to improve the current reality.

Al-Rahahleh (2006) study aimed at evaluating teaching plans and method used by accounting system in Al-Bayt University and identifying to which extent they are compatible with university philosophy and mission plus the requirement of this age. For achieving the purposes of the study, a set of question were answered as follows: Are the courses compatible with university philosophy? What are the skills and competencies the student acquires during his/her studying? What are the shortcomings of teaching plan? For achieving the purposes of the study, the researcher used content analysis of teaching plan and descriptive statistics of data analysis. In addition, 85 questionnaires were distributed to all students expected to graduate in academic year 2004/2005. Out of 85 questionnaires, 60 questionnaires have been valid. The study found that there is a need to review teaching plans, method and means that have not been compatible with university philosophy and the requirements of the age. Finally, the study recommended that teaching plans should be reviewed and electronic teaching methods should be inserted in teaching process.

Hijawi, Al-Fadl (2005) study aimed at evaluating accounting curricula and their role in building the vocational skills of graduates. It also illustrated the possibilities available for evaluating accounting curricula and the effect of the curricula of building professional skills. The study also identified the methods of developing these curricula. The researcher pointed out that there is a lack of accounting curricula which diminishes the professional skills. Finally, the study found that vocational skills have decreased due to a failure of curricula. in addition, there is a clear gap between the requirements of labor market and accounting education outcomes; and the recent curricula do not qualify the graduates. The study also found that curricula do not contain analytical approaches and don not interest in practical training. Finally, the study recommended that accounting teaching methods and programs used by higher education institutes should be reviewed.

Hells (2005) study aimed at evaluating the effectiveness of teaching in accounting department of the Islamic University from the point of view of the students. Teaching's effectiveness has been identified by various axes: material, subjects, the book, auxiliary readings, homework, examinations and teacher. The researcher designed a questionnaire and distributed it to a random sample of the students of accounting department during the academic year 2002/2003. The study showed that the paragraphs pertaining to teaching's effectiveness have positively evaluated by the students; the answers of all paragraphs have been: agree, strongly agree; the ration has been more that $50 \%$.

Al-Jahmani (2000) study aimed at identifying the most important factors taken by employment managers as main pillars of employing new accountants; the importance of these factors are determined according to economic sector. For achieving the purposes of the study, a questionnaire has been distributed to a sample of 85 Jordanian financial, industrial, and commercial and service institutes of private sector in order to collect data. The questionnaire consisted of four groups pertaining to academic achievement, practical experience, one team spirit factors and candidate's personal factors; calculations, standard deviations and single-variance analysis have been used in order to test research hypotheses. The study found that there is a relationship between the four groups and the decision of employing new accounting; and employment managers have interested in personal factors, one team spirit followed by previous experience and academic achievement. The results showed that 
there have been statistically significant differences between one team spirit factors and their impact on the decision of employing new accountants in various sectors. These differences have been in favor of financial and commercial sectors. Regarding to academic achievement, the researcher has interested in, the study found that the most important factor has been the ability of applicant of using computer programs, followed by applicant's cumulative average of university certificate, then his/her marks of English language courses, and two accounting courses 1 and 2, and other accounting courses, and getting certificate of legal accountant and the university he graduated from; the study showed that other remaining three factors have related to the evaluation of applicant's professors, his mark of mathematics and the desire to complete his higher education. Finally, the study recommended that the university should refine student personality and focus on educational aspects; the university also need to deal with labor work in order to cope with the developments of external environment. Finally, the study showed that academic achievement and its relevant factors are important and university's teaching plans shall depend on these factors in order to increase job opportunities the undergraduates may obtain.

Al-Hajiri (2000) study showed that using computer as a tool of evaluating the courses and teaching methods ( lectures, examinations and evaluation) is a new broad trend of scientific research field. The study sought to design a flexible software system of education as a substitute for the traditional educational system, currently used by the universities and schools; it also could be used as a self-education system helping the persons who could not enroll in universities or schools or could not attend educational courses held by universities or other institutes. This software system, designed and tested, serves two parties: the teacher and the student; the teacher has to prepare lecture and relevant questions and insert them in the system; then, the student has to use the system in order to learn the subjects prepared by the teacher and answer the questions inserted by the teacher in order to figure out to which extent the students comprehend the lecture. In addition, the system can determine his/ her abilities through three levels provided by the system. Furthermore, by using this system, the teacher can add new subjects to the previous lecture, delete subjects that are not longer relevant or modify the questions prepared by lecture's subjects. Moreover, the teacher can use the system in order to conduct an examination without having to write the questions or answers on the papers. Depending on previous question inserted, The system can be also directed to prepare and directly grade the examination during a specific time determined and controlled by the teacher. After examination, students' grades are showed directly. Accordingly, students' complaints pertaining to the results are eliminated because the grades are immediately known by the students. The proposed educational system has been used in conducting the final examination of 50 computer software students in the second academic semester $97 / 98$ and has been tested. Thus, the results showed that conducting examination by using this system has not been expensive; examination's questions have been highly confident and secure; finally, this system eliminates cheating method compared to the current system. The researcher showed that the study is distinguished because it has touched upon curricula of accounting department and has identified to which extent they are compatible with the impact of information technology on the accounting; in addition, it identifies scientific and knowledge requirements of accounting of accountants.

\subsection{Theoretical Framework}

\subsubsection{Accounting Curricula and Information Technology}

Knowledge concept is the understanding of information obtained by studying and learning. Knowledge is defined by (Hilali, 2004, p.24) as "an accumulated balance of information and long experience and study in a certain field." Knowledge and skills can be obtained by primary and higher academic study of specialization field. Regarding accounting study, vocational preparation needs to obtain a suitable levels of non-vocational knowledge pertaining to general subjects and learning and vocational knowledge which contains the following:

1. Accounting, finance and associated knowledge

2. Organizational and commercial knowledge,

3. And IT knowledge and its specialties.

International federal of accountants ensures that the vocational preparation of accountants shall contain subjects of IT knowledge as follows:

1. IT general knowledge.

2. knowledge of Control system of information technology

3. Knowledge and skills which the accountant, working in the capacity of IT user, has to have.

4. Knowledge and skills which the accountant, working in the capacity of manager, evaluator and designer in IT enviroment, has to have. 
These knowledge and skills are illustrated as follows:

\section{- $\quad$ IT general knowledge}

It touches upon general concepts of information technology in business environment. It also includes system theory, types and goal of systems, system structure, control and feedback systems, information nature and types and the role of information in organization environment. In addition, it contains decision theory, human resources information, operation system information and financial analysis. This knowledge also illustrates physical components including computer configuration units, processing units, input and output units, processing speeds, information storage units, and connectivity and communication units. It also identifies methods of linking and transforming data, methods of linking document and messages and operational management and control.

\section{- $\quad$ knowledge of Control system of information technology}

Such knowledge aims at ensuring the understanding of knowledge of control system and it includes the following subjects:

1. Illustrating the objectives of control extracted from the study of the risks associated with information technology.

- $\quad$ Identifying possibilities of penetrating computerized information system;

- Understanding the impact of computer on control process;

- Understanding the impact of information technology on organizations and control systems

- $\quad$ Identifying the responsibility of control;

- Identifying the capability and effectiveness of processes and their impact on the credibility of financial reports;

- $\quad$ Formulating and using the procedures of control at the lowest costs.

2. Structuring the control

3. Identifying control environment through understanding the philosophy and operational method of the management; structuring the institute and its plans plus communication means.

4. Evaluating the risks through identifying the risks of penetrating the information systems, the possibility of loss and plans of discovering and correcting the errors plus illustrating preventive treatment.

5. Identifying control activities which include the understanding of accounting system functions, the procedures of accounting and administrative control, design of control systems, availability of control of integrity and confidentiality of information.

6. Ensuring the availability of continuity of operations, restoration of information, and planning and control.

7. Monitoring the compatibility with control systems and the role played by their users of mangers and external and internal auditors.

\section{- Knowledge and skills which the accountant, working in the capacity of IT user, has to have.}

International standards of accounting education outlined the most significant skills and knowledge the accountant as a user of IT has to have; the accountant shall have the ability to deal with various accounting educational software programs.

- Knowledge and skills which the accountant, working in the capacity of manager, evaluator and designer in IT environment, has to have

Specialists of accounting appreciate the role played by information systems in achieving the purposes and needs of organizations. Studying this subject should be done by using the systems in real business environment. After adopting the basic tools, the following question arose : How can the basic software such as operation systems, word processing systems and electronic tables be used?). Information systems should be studied as integrative systems which do not work as independent unit.

These subjects include various knowledge and skills which the accountant, working in the capacity of manager of information system in IT environment, has to have. Such knowledge and skills aimed at identifying various types of information systems which link to financial systems and understanding the internal control and the roles played by the systems in making decision through data processing systems. They also aimed to illustrate the basic tools of analyzing, designing, developing and applying the information systems. Such knowledge and skills 
illustrate the systems of data application and protection plus the available tools that improve the efficiency of project performance in addition to the procedures that ensure the accuracy of system work. They also seek to understand the role and importance of e-commerce in current business environment and manage system maintenance process.

\section{Data Analysis and Hypotheses Testing}

This section of the study outlines the results concluded by a field study; in light of the purposes, questions and hypotheses of the study, these results are discussed. In this section, a detailed description of demographic and functional characteristics of study sample. Then, the hypotheses of the study shall be tested.

1- Functional characteristics

2- Demographic characteristics of study respondents

Table 1 outlines the demographic characteristics of study respondents; these characteristics are as follows: public or private university, Grade Average, Academic degree, and occupation.

Table 1. Distribution of study respondents

\begin{tabular}{llll}
\hline Variable & Category & Number & Percentage\% \\
\hline \multirow{3}{*}{ University } & public & 30 & 27.5 \\
Grade Average & private & 87 & 72.5 \\
& Very good & 100 & 83.3 \\
& Pass & 5 & 4.2 \\
good & Excellent & 4 & 3.3 \\
Academic degree & Master & 11 & 9.2 \\
& BA & 47 & 39.1 \\
Occupation & PHd & 57 & 47.5 \\
& Trained accountant & 16 & 13.3 \\
& accountant & 17 & 14.2 \\
& Trained auditor & 56 & 46.7 \\
\hline
\end{tabular}

Table 1 illustrates the following results:

\section{First: (Public or private) Universities}

The highest percentage of study respondents noted in Table 1 is the graduates of public universities; the supplementary percentage is the graduates of private universities. The results showed that this study has touched upon Jordanian higher education and scientific research institutes, thereby contributing to develop and modernize universities' teaching plans.

\section{Second: Grade Average}

The highest percentage of student respondents noted in table 1 is the graduates whose grade average is very good; the percentage has been 83.3. The results showed that a high percentage of study respondents know well the subject and able to answer study questions.

\section{Third: Academic Degree}

Table 1 shows that the percentages of student respondents who hold BA degree, MA degree and PHD degree have been 47.5, 39.1, and 13.3, respectively. The results have indicated that study respondents hold various academic degrees; and necessary knowledge and skills of various academic degrees are available. Consequently, these results contribute to strengthen the study.

\section{Fourth: Occupation}

Table 1 indicates that the percentages of study respondents who work in the capacities of trained accountant, accountant, trained auditor and auditor have been $14.2 \%, 46.7 \%, 13.3 \%$ and $25.8 \%$, respectively. The results have illustrated that these occupations reflect different requirements of labor work according to their various needs. 


\subsection{Hypotheses Testing}

In this section, hypotheses study are tested and discussed according to four axes of the study.

First hypothesis: Accounting curricula taught in Jordanian higher education and scientific research institutes include general knowledge which the accountant has to know well in order to meet the requirements of Jordanian labor market and IT environment.

For validating this hypothesis, arithmetic means, standard deviations of paragraphs pertaining to first hypothesis have been extracted; they have been outlined in table 2 .

Table 2. Arithmetical averages, standard deviations of paragraphs pertaining to first hypothesis ( in descending order according to arithmetic means)

\begin{tabular}{llcl}
\hline \multicolumn{3}{l}{ Following paragraphs measure to which extent the general knowledge and skills are available in IT environment } \\
\multicolumn{2}{l}{$\begin{array}{l}\text { No. } \\
\text { Accounting education programs in Jordanian universities include the following knowledge and skills: }\end{array}$} & \multicolumn{2}{l}{ Standard deviation } \\
\hline 1 & Concept of information technology & 4.27 & .645 \\
2 & The goals of information system & 4.27 & .658 \\
3 & System elements : 1. Human element ( Human resources) & 4.20 & .693 \\
4 & 2. hardware & 4.18 & .710 \\
5 & 3.software & 4.17 & .702 \\
6 & 4.Data base & 4.16 & .674 \\
7 & 5. control element & 4.14 & .714 \\
8 & System procedures & 4.13 & .668 \\
9 & Electronic works & 4.07 & .742 \\
10 & E-commerce & 4.03 & .744 \\
11 & Electronic publishing of financial and non-financial data & 4.03 & .744 \\
12 & Concept of electronic networks and using them in organization & 4.03 & .744 \\
& environment & & .744 \\
\hline
\end{tabular}

Table 2 shows arithmetic means, standard deviations of paragraphs pertaining to the first hypothesis. Arithmetic means have ranged between $(4.03-4.27)$. Paragraph 1 pertaining to the knowledge, concept and goals of information systems which the graduates know, has the first rank with an average of 4.27. The paragraphs 10 to 13 which touch upon the knowledge pertaining to e-commerce, electronic publishing and accounting records and books have the last rank with an average of 4.03 .

Arithmetic mean average has been compared to standard value 3 - acceptance criterion of hypothesis- by using $\mathrm{t}$-test as stated in table 3 .

Table 3. Arithmetic means, standard deviations and t-test of the paragraphs

\begin{tabular}{|c|c|c|c|c|c|c|}
\hline $\begin{array}{l}\text { Accounting curricula in Jordanian } \\
\text { higher education and scientific } \\
\text { research institutes includes general } \\
\text { knowledge which the accountant has } \\
\text { to know well in order to meet the } \\
\text { requirements of Jordanian labor } \\
\text { market and IT environment. }\end{array}$ & No. & Arithmetic mean & $\begin{array}{l}\text { Standard } \\
\text { deviation }\end{array}$ & T-value & $\begin{array}{l}\text { Degrees } \\
\text { of } \\
\text { freedom }\end{array}$ & Statistical significance \\
\hline & 120 & 4.16 & 23. & 191.72 & 119 & 000 . \\
\hline
\end{tabular}

Table 3 shows that curriculum in Jordanian higher education presents the general information of electronic system through computer courses 1 and 2 and accounting applications; e-commerce course is optional in some universities.

Second hypothesis: Accounting curricula taught in Jordanian higher education and scientific research institutes include the knowledge and skills which meet the requirements of Jordanian labor market and qualify the students to work in IT environment in the capacity of electronic system users. 
For validating this hypothesis, arithmetic means, standard deviations of paragraphs pertaining to first hypothesis have been extracted; they have been outlined in table 4 .

Table 4. Arithmetic means, standard deviations of paragraphs pertaining to the second hypothesis ( in descending order according to arithmetic means)

\begin{tabular}{|c|c|c|c|}
\hline \multicolumn{4}{|c|}{ General knowledge and skills contributing to qualify the accountant as information system user in IT environment } \\
\hline No. & Paragraphs & Arithmetic mean & Standard deviation \\
\hline \multicolumn{4}{|c|}{ Accounting courses taught in Jordanian universities include the following knowledge and skills: } \\
\hline 1 & Using accounting ready-made software & 4.19 & .690 \\
\hline 2 & Using electronic tables & 4.15 & .706 \\
\hline 3 & $\begin{array}{l}\text { Understanding accounting systems and subsystems and the } \\
\text { relevant relationships }\end{array}$ & 4.15 & .741 \\
\hline 4 & Preparing the data by using database & 4.12 & .735 \\
\hline 5 & Displaying and disclosing the data by using database & 4.10 & .666 \\
\hline 6 & Using opened database & 3.97 & .679 \\
\hline 7 & Using ready-made auditing programs & 3.97 & .732 \\
\hline 8 & Accounting records and books in IT environment & 3.97 & .704 \\
\hline 9 & Evaluating accounting and internal control systems & 3.85 & 657 \\
\hline
\end{tabular}

Table 4 shows arithmetic means, standard deviations of paragraphs pertaining to the second hypothesis. Arithmetic means have ranged between $(3.85-4.19)$. Paragraph 1 pertaining to the using accounting ready-made software has the first rank with an average of 4.19. Paragraph 9 which touches upon the ability of graduates to evaluate internal control and accounting programs has the last rank with an average of 3.85.

The hypothesis has been tested by using t-test as noted in table 5 .

Table 5. Arithmetic means, standard deviations and t-test of the paragraphs compared to standard value 3

\begin{tabular}{|c|c|c|c|c|c|c|}
\hline $\begin{array}{l}\text { Accounting courses taught in } \\
\text { Jordanian higher education and } \\
\text { scientific researcher institutes } \\
\text { include the knowledge and skills } \\
\text { which meets the requirements of } \\
\text { Jordanian labor market and qualify } \\
\text { the students to work in IT } \\
\text { environment in the capacity of } \\
\text { electronic system users. }\end{array}$ & No. & Arithmetic mean & $\begin{array}{l}\text { Standard } \\
\text { deviation }\end{array}$ & T-value & $\begin{array}{l}\text { Degrees } \\
\text { of } \\
\text { freedom }\end{array}$ & Statistical significance \\
\hline & 120 & 3.88 & 0.29 & 136.33 & 119 & 000. \\
\hline
\end{tabular}

Table 5 shows that courses taught in Jordanian higher education and scientific research institutes include the knowledge and skills which meets the requirements of Jordanian labor market and qualify the students to work in IT environment in the capacity of electronic system users.

Third hypothesis: Accounting curricula taught in Jordanian higher education and scientific research institutes includes control- related knowledge and skills which meet the requirements of Jordanian labor market and IT environment.

The paragraphs measures to which extent the courses present control-related knowledge and skills in IT environment.

For validating this hypothesis, arithmetic means, standard deviations of paragraphs pertaining to third hypothesis have been extracted; they have been outlined in table 6 . 
Table 6. Arithmetic means, standard deviations of paragraphs pertaining to third hypothesis ( in descending order according to arithmetic means)

\begin{tabular}{llll}
\hline \multicolumn{2}{l}{ Control-related knowledge and skills in IT environment } & \\
No. & Paragraphs & Arithmetic mean & Standard deviation \\
Accounting courses taught in Jordanian universities include the following knowledge and skills: & \\
1 & Concept of control in IT environment & 4.27 & .648 \\
2 & Information system risks & 4.25 & .651 \\
3 & The importance of control in IT environment & 4.09 & .756 \\
4 & Control procedures in IT environment & 3.99 & .716 \\
5 & Control regulations in IT environment & 3.97 & .654 \\
6 & General control's regulations & 3.97 & .673 \\
7 & Applied control's regulations & 3.93 & .742 \\
8 & Works and e-commerce risks & 3.93 & .936 \\
9 & Security and protection procedures & 3.92 & .784 \\
\hline
\end{tabular}

Table 6 shows arithmetic means, standard deviations of paragraphs pertaining to third hypothesis. Arithmetic means have ranged between ( 3.92 - 4.27). Paragraph 1 pertaining to Concept of control in IT environment has the first rank with an average of 4.27. Paragraph 9 which touches upon the knowledge and skills of security and protection procedures has the last rank with an average of 3.92 .

The hypothesis has been tested by using t-test as noted in table 7 .

Table 7. Arithmetic means, standard deviations and t-test of the paragraphs compared to standard value 3

\begin{tabular}{lllllll}
\hline $\begin{array}{l}\text { Accounting courses taught in Jordanian higher education } \\
\text { and scientific research institutes includes control- related } \\
\text { knowledge and skills which meet the requirements of }\end{array}$ & No. $\begin{array}{l}\text { Arithmetic } \\
\text { mean }\end{array}$ & $\begin{array}{l}\text { Standard } \\
\text { deviation }\end{array}$ & T-value & $\begin{array}{l}\text { Degrees of } \\
\text { freedom }\end{array}$ & $\begin{array}{l}\text { Statistical } \\
\text { significance }\end{array}$ \\
\hline Jordanian labor market and IT environment & 120 & 3.92 & 0.29 & 136.33 & 119 & 000. \\
\hline
\end{tabular}

The results indicate that accounting courses include control- related knowledge and skills in order to meet Jordanian labor market and IT market; such knowledge and skills are integrated in audit and accounting information system courses and are not given in one specialized course.

Fourth hypothesis: Accounting curricula taught in Jordanian higher education and scientific research institutes include the knowledge and skills which qualify the accountants in order to work in IT environment in the capacities of electronic system managers, designers and evaluators and meet Jordanian labor market.

The paragraphs measure the knowledge and skills available in accounting courses and qualify the accountant in order to work in the capacity of electronic system manager, designer and evaluator.

For validating this hypothesis, arithmetic means, standard deviations of paragraphs pertaining to fourth hypothesis have been extracted; they have been outlined in table 8 . 
Table 8. Arithmetic means, standard deviations of paragraphs pertaining to fourth hypothesis ( in descending order according to arithmetic means)

\begin{tabular}{|c|c|c|c|}
\hline \multicolumn{4}{|c|}{ knowledge and skills which qualify the accountants in order to work in IT environment in the capacity of electronic system manage } \\
\hline No. & Paragraphs & Arithmetic mean & Standard deviation \\
\hline \multicolumn{4}{|c|}{ Accounting courses taught in Jordanian universities include the following knowledge and skills: } \\
\hline 1 & $\begin{array}{l}\text { The impact of information technology on the components of } \\
\text { accounting system }\end{array}$ & 3.97 & .673 \\
\hline 2 & The ability of strategic planning of information technology & 3.93 & .742 \\
\hline 3 & $\begin{array}{l}\text { The ability of using information technology in administrative } \\
\text { tasks such as planning, control and decision making }\end{array}$ & 3.93 & .936 \\
\hline 4 & $\begin{array}{l}\text { The ability of operating information technology and } \\
\text { understanding operation types }\end{array}$ & 3.92 & .784 \\
\hline 5 & $\begin{array}{l}\text { The ability of drawing up and administrating life cycle of } \\
\text { information system }\end{array}$ & 3.91 & .889 \\
\hline 6 & The ability of enhancing investment analysis using software & 3.88 & 1.030 \\
\hline 7 & The ability of selecting operation systems & 3.84 & .870 \\
\hline 8 & The ability of selecting copy and save files' ways & 3.78 & .641 \\
\hline 9 & The ability of selecting equipments, hardware, and software & 3.69 & .994 \\
\hline
\end{tabular}

Table 8 shows arithmetic means, standard deviations of paragraphs pertaining to fourth hypothesis. Arithmetic means have ranged between ( 3.69 -3.97). Paragraph 1 pertaining to The impact of information technology on the components of accounting system has the first rank with an average of 3.97. Paragraph 9 which touches upon the ability of selecting equipments, hardware, and software has the last rank with an average of 3.69.

Table 9. Arithmetic means, standard deviations of paragraphs pertaining to fourth hypothesis ( in descending order according to arithmetic means)

\begin{tabular}{llll}
\hline \multicolumn{3}{l}{ knowledge and skills which qualify the accountants in order to work in IT environment in the capacity of electronic system designers } \\
No. & $\begin{array}{l}\text { Arithmetic mean } \\
\text { Saragraphs }\end{array}$ & \\
\multicolumn{2}{l}{ Accounting courses taught in Jordanian universities include the following knowledge and skills: } \\
\hline 1 & Symbols used in designing accounting information systems & 4.19 & .690 \\
2 & Stages of designing accounting information systems & 4.15 & .706 \\
3 & Drawing and developing logic maps of data flow & 4.15 & .741 \\
4 & Drawing and developing maps of document flow & 4.12 & .735 \\
5 & Drawing and developing maps of program flow & 4.10 & .666 \\
6 & Accounting information system design course & 3.97 & .679 \\
7 & Principles adopted in designing accounting information system & 3.97 & .732 \\
8 & Cost of accounting information system investment & 3.85 & .657 \\
\hline
\end{tabular}

Table 9 shows arithmetic means, standard deviations of paragraphs pertaining to fourth hypothesis. Arithmetic means have ranged between (3-4.19). Paragraph 1 pertaining to knowledge and skills of symbols used in designing accounting information systems has the first rank with an average of 4.19. Paragraph 8 which touches upon the knowledge and skills of Cost of accounting information system investment has the last rank with an average of 3.85 . 
Table 10. Arithmetic means, standard deviations of paragraphs pertaining to fourth hypothesis ( in descending order according to arithmetic means)

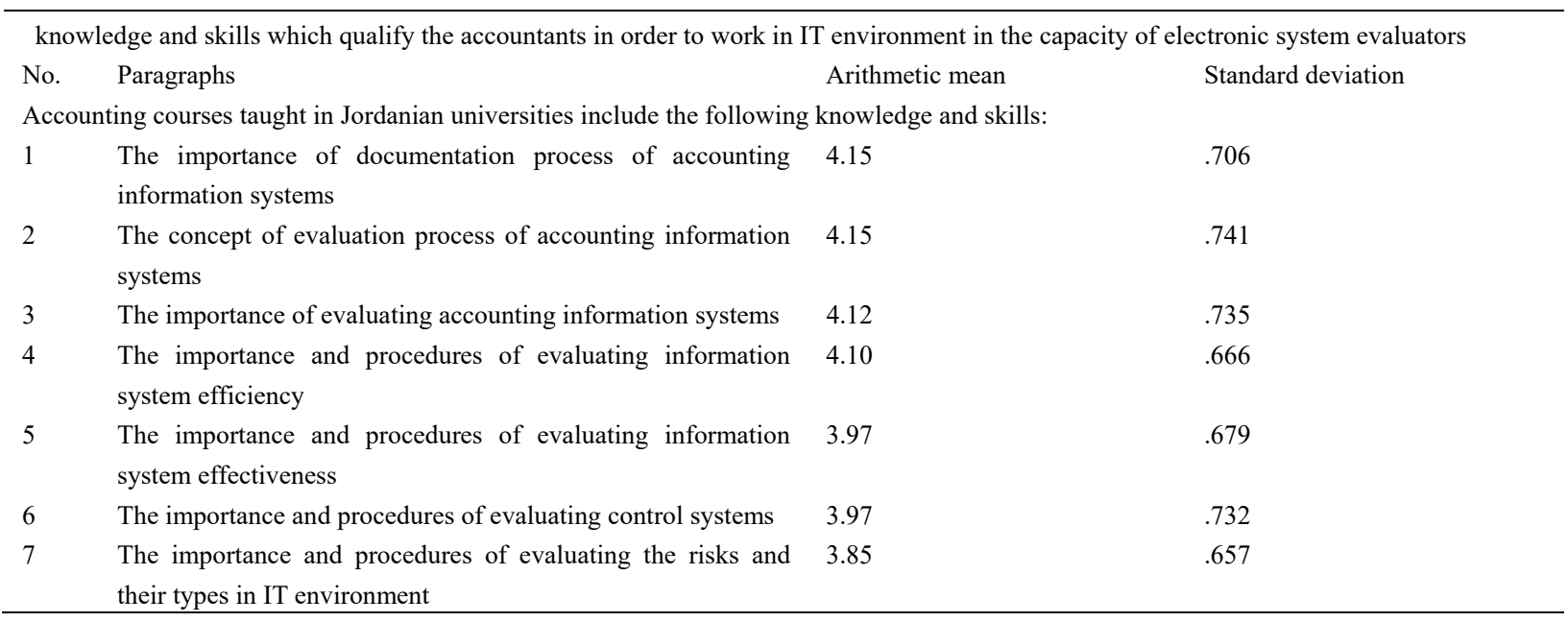

Table 10 shows arithmetic means, standard deviations of paragraphs pertaining to fourth hypothesis. Arithmetic means have ranged between (3.85-4.10). Paragraph 1 pertaining to knowledge and skills of the importance of documentation process of accounting information systems has the first rank with an average of 4.15. Paragraph 7 which touches upon the knowledge and skills of the importance and procedures of evaluating the risks and their types in IT environment has the last rank with an average of 3.85 .

The hypothesis has been tested by using t-test as noted in table 11 .

Table 11. Arithmetic means, standard deviations and t-test of the paragraphs compared to standard value 3

\begin{tabular}{|c|c|c|c|c|c|c|}
\hline $\begin{array}{l}\text { Accounting courses taught in } \\
\text { Jordanian higher education and } \\
\text { scientific research institutes include } \\
\text { the knowledge and skills which } \\
\text { qualify the accountants in order to } \\
\text { work in IT environment in the } \\
\text { capacities of electronic system } \\
\text { managers, designers and evaluators } \\
\text { and meet Jordanian labor market. }\end{array}$ & & Arithmetic mean & $\begin{array}{l}\text { Standard } \\
\text { deviation }\end{array}$ & T-value & $\begin{array}{l}\text { Degrees } \\
\text { of } \\
\text { freedom }\end{array}$ & Statistical significance \\
\hline & 120 & 3.9 & 0.31 & 137.4 & 119 & 000. \\
\hline
\end{tabular}

The results noted in table 11 indicate that accounting courses cover all previous subjects which have been inserted in teaching plans of auditing and information technology courses with varying degrees.

\section{Results}

Based on field study and hypothesis testing, the researcher has reached the following results:

1. Accounting courses taught in Jordanian higher education and scientific research institutes includes general knowledge which the accountant has to know well in order to meet the requirements of Jordanian labor market and IT environment.

2. Accounting courses taught in Jordanian higher education and scientific research institutes include the knowledge and skills which meets the requirements of Jordanian labor market and qualify the students to work in IT environment in the capacity of electronic system users.

3. Accounting courses taught in Jordanian higher education and scientific research institutes includes controlrelated knowledge and skills which meet the requirements of Jordanian labor market and IT environment.

4. Accounting courses taught in Jordanian higher education and scientific research institutes include the knowledge and skills which qualify the accountants in order to work in IT environment in the capacities of electronic system manager, designer and evaluator and meet Jordanian labor market. 


\section{Recommendations}

The study has recommended the following:

1. Accounting courses taught in accounting departments shall be restructured according to specific plan and pre-defined criteria in a manner that responds to the requirement of practical reality. This procedure can be done by consolidating accounting courses taught in public and private universities and focusing on the caps of information systems and their impact on financial and accounting systems plus the relative risks.

2. Higher education and scientific research institutes shall improve the abilities of faculty member to teach, develop the plans, programs, courses and use technology; he /she shall also be encouraged to develop his /her research abilities.

3. Faculty members shall be allowed to practice the profession in a manner that is not inconsistent with their academic works since such matter contributes to develop educational and vocational processes.

4. Course's teaching file shall be paid attention because it is an effective way of self-evaluation of faculty member. Such way helps faculty member to identify the methods that may improve his /her teaching performance.

5. Scientific references and books which are consistent with the continuous accounting and vocational developments and meet the requirements of teaching file shall be provided. In addition, faculty members shall be encouraged to write books in a way that serve various teaching courses.

6. Continuous education is necessary in order to improve the skills and keep up with modern developments of information technology.

7. Academics and practitioners shall cooperate in order to identify the needs of practical practice, and figure out to which extent education programs meet the requirements of developed application.

8. Teaching method followed by accounting departments shall be reviewed in a way that creates a strong link between theoretical study and practical application.

9. Case study shall be focused on as a method of approximating the theoretical aspect for practical aspect of lectures. In addition, in accounting departments, laboratory method shall be used, especially in accounting subjects, mostly used in scientific reality.

10. Evaluation method followed in accounting courses shall be reviewed; weaknesses shall be used in developing evaluation methods which have more than one side such as exercises, researches, discussion, attendance, partial and final examination; modern methods of preparing examinations shall be followed.

11. Admission requirements of higher studies shall be reviewed and developed according to certain criteria so that they do not only depend on academic degrees and entrance examinations of accounting field but rather depend on the level of ICT skills possessed by the applicants.

12. Higher study programs in accounting departments shall be developed; and researchers shall be encouraged to write and translate researches and books in accounting field. In addition, scientific researches shall be published and supported and distinguished researches shall be rewarded.

13. Educational aspects of accounting education programs such as goals, faculty members, students, courses, teaching methods and techniques, assessment methods, educational administration and financial and human resources shall be continuously assessed.

14. Attention shall be paid to ethical dimension of accounting education and a code of ethics defining the parameters of ethical dimension shall be created.

15. Continuous meetings between faculty members of accounting departments in Jordanian universities shall be held in order to discuss the problems face these departments and propose suggestions of developing courses and teaching methods.

16. The problems of practical application of economic units shall be addressed and solved by accounting departments through providing the required data.

17. Scientific research in accounting field shall be linked to the problems of practical application of economic units through providing the required data in order to solve these problems. 


\section{References}

Abd, A. N. M. F., \& Mustafa, M. A. H. (2007). The Impacts of Some Factors on the Level of Achievement of Students of Economic Science Secondary schools. Published Paper in Scientific Conference of Accounting Education, Academy of Higher Study, Tripoli, Libya.

Al-Aidrus, M. A. O. (2000). Extent of keeping up with Accounting Profession and Reviewing of Economic Developments in Republic of Yemen. Unpublished master thesis. Sudan, Al-Jazira University, Faculty of Economics and Rural Development, Department of Accounting and Finance

Bin, R. A. A. S. (2006). Accounting Education in Accounting Departments in Saudi Universities.

Bofaris, R. A. (2007). Vocational Accounting Education "Reality and Means of Developments" Published Paper in Scientific Conference of Accounting Education, Academy of Higher Study, Tripoli, Libya.

Elliott, R. K. (1992). The third wave breaks on the shores of accounting. Accounting Horizons.

Ghaith, S., Faraj, A. B. (2007). Factors Affecting the Efficiency of Educational Process and Their Impact On The Students. Published Paper in Scientific Conference of Accounting Education, Academy of Higher Study, Tripoli, Libya.

Mohammad, S., \& Basheer, K. (2009). The Impact of the Participation of Accountants of developing accounting systems on the success of these systems and their impact on Company's Financial Performance. Jordanian Journal of Business Administration, 5(2), 182-203.

Qatani, K., \& Aweys, K. (2009). The extent of compatibility of Accounting Curricula in Omani Universities with the requirements of labor market in Light of the Repercussions of Financial Crisis. Al-Zahra College, Muscat, Sultanate of Oman.

Tala, H., \& Moayad, A. F. (2005). Evaluation of the Role of Accounting Curricula In Building Vocational Skills and Their Development Trends. The Arab Journal of Accounting, 8(1), 27-47.

Tantoush, M. Q., \& Tantoush, T. M. (2007). The Requirements of Accounting Profession and the Need For Dual Accounting Education. Published Paper in Scientific Conference of Accounting Education, Academy of Higher Study, Tripoli, Libya.

Walid, S., \& Yassin, R. (2008). Personal Factor Affecting the benefit of Electronic Accounting higher Education: Case Study. Hashemite University, Published Study, Faculty of Finance and Administration, Al-Bayt University.

\section{Copyrights}

Copyright for this article is retained by the author(s), with first publication rights granted to the journal.

This is an open-access article distributed under the terms and conditions of the Creative Commons Attribution license (http://creativecommons.org/licenses/by/4.0/). 